\title{
Analysis of Merger \& Acquisitions Motivation and Post Performance of Internet Corporations in China-A Case Study of Youku Merger with Tudou
}

\author{
Ziyu Huang \\ International Business school \\ Yunnan University of Finance and Economics \\ Yunnan, China \\ 704381101@qq.com
}

\author{
Xiaojiao Ye* \\ School of Economics \\ International Business school \\ Yunnan University of Finance and Economics \\ Yunnan, China \\ 997463214@qq.com
}

\begin{abstract}
With the maturity of China's Internet industry, the Chinese Internet industry has entered a new wave of mergers and acquisitions. This study takes the merger and acquisition case of the two largest online video companies in China as an example, Youku and Tudou. Its goal is mainly to analyse the motivation and performance of the Internet companies' merger. In this study, cumulative abnormal return (CAR) is mainly used as a measure of profitability. The results show that as of the date of the merger announcement, Youku's CAR keeps at a positive value. The market responded positively to Youku merge with Tudou, showing a positive short-term effect. The study concludes that the motives for Chinese Internet companies' mergers and acquisitions are still focused on increasing market share and achieve synergy.
\end{abstract}

Keywords-China Internet company; $M \& A ; M \& A$ performance

\section{INTRODUCTION}

As China's Internet industry matures, the Internet as a driving force for economic development and social progress has become increasingly prominent. The Chinese Internet industry has entered a new wave of mergers and acquisitions.

According to the statistics of Zero2IPO Research Centre [1], in the Internet industry, 278 transactions in the disclosed amount involved a total transaction value of US\$14.349 billion in 2012. According to the 41st China Internet Statistics Report issued by CNNIC [2], the use coverage of online video in netizens has reached $75 \%$ in 2017 . The development of online video corporations is gradually ushering in greater market demand.

The Internet video industry belongs to the Internet industry and is an industry that relies on the Internet to operate. iResearch [3] showed that the whole industry is generally in the dilemma of loss-making business, whether it is funding problems, or profit issues, have caused great distress for online video corporations.

Since Youku merge with Tudou launched the wave of mergers and acquisitions in China's Internet video industry in 2012 , this poses new challenges to accelerate the integration of the industry. This study based on the phenomenon of emerging Internet industry mergers and acquisitions, effectively complements the existing theories of merger and companies and provide a series of products or services to acquisition motivation and performance. On this basis, this dissertation selected two leading corporations in the online video industry, Youku and Tudou, focusing on the analysis of corporate motives and performance impacts, providing some inspiration and lessons for the future M\&A activities of the Chinese Internet industry.

This study based on the phenomenon of emerging Internet industry mergers and acquisitions, effectively complements the existing theories of merger and acquisition motivation and performance. On this basis, this dissertation selected two leading corporations in the online video industry, Youku and Tudou, focusing on the analysis of corporate motives and performance impacts, providing some inspiration and lessons for the future M\&A activities of the Chinese Internet industry.

\section{LITERATURE REVIEW}

\section{A. Mergers and Acquisitions}

Mergers and acquisitions are actions that a company purchases most or all of its assets in order to control another company. It is generally the dominant entity that combines the weaker development ability. Acquisition refers to the purchase of another company's stock in the form of cash or securities and an enterprise's control over the company [4]. Another concept is the merger, mainly the merger of several companies into a new enterprise [5].

This kind of economic behaviour has at least two advantages: First, it brings more competitive advantages to the bidding company; Second, it is beneficial to the merger and acquisition group to achieve business objectives [6]. However, there are also shortcomings, due to the information asymmetry between M\&A parties, hidden risks and costs [7].

M\&A can be divided into three basic types: Horizontal Merger, Vertical Merger, and Conglomerate Merger. Horizontal Merger refers to mergers and acquisitions between two or more companies that produce and sell the same or similar products, that is, mergers and acquisitions between companies in the same industry [8]. Youku merge with Tudou can be defined as horizontal Merger. Horizontal Merger can eliminate redundant facilities between Internet complement each other's strengths and achieve market share

*Corresponding author 
expansion [9]. Vertical Merger refers to mergers and acquisitions that occur between companies that have a high degree of correlation with a company's production process or business process, or that are engaged in different stages of a product's business [10]. Conglomerate merger refers to mergers and acquisitions between companies that are not directly related to the supply of products required by the company, the production of goods, or the sale of finished products [11].

\section{B. Motivation of Merger and Acquisition}

\section{1) Synergies}

Horizontal acquisitions create value by using synergies based on cost and revenue.

Corporate mergers and acquisitions can achieve some sort of synergy, which is the effect of $1+1>2$. Song and Petti [12] used empirical research pointed out that M\&A can improve the company's efficiency and effectiveness, complement each other's resources, and thus increase the value of the target company and achieve the synergy effect of M\&A. Fulghieri and Sevilir [13] use model of endogenous synergy creation and shows the synergies of mergers and acquisitions will only be realized within a few years after the merger. Wang and Liu [14] analysed the short-term market performance of the tendering company through test methods, and the data presented positively to CAR, which achieved short-term financial synergy.

The complexity of Synergistic mergers also leads to integration issues. From the perspective of the bidding company, the acquisition may not be favourable. Because they may cost too much [15], leading to negative synergies [16], or mainly driven by the interests of top managers [17].

The future benefits of Internet companies' mergers and acquisitions are difficult to predict. Yang [18] uses the risk framework to identify risks in China's Internet M\&A companies, the experimental results show that it improves financial performance but there is also integrated risk. Ma [19] analysed the financial ratio of Tencent, the conclusion shows the positive effects of financial synergies for Internet companies' M\&A include: improving profitability and improving financial management. Negative effects include integration of risks and costs, operational Risks, and financing risks. Zhao and Wang [20] used the empirical research model to analyse panel data of 44 Chinese Internet companies listed in Hong Kong and the United States, it found the mergers and acquisitions of Internet companies have enabled companies to absorb and integrate new external resources and reconfigure and optimize assets in synergies.

\section{2) Monopoly and market competition theory}

Companies often use acquisitions to increase market share, customer groups, and market forces. Fee and Thomas [21] and Shahrur [22] examined data sample has proved that the monopoly power of upstream market suppliers has clearly contributed to the synergistic effect of horizontal mergers. Huyghebaert and Luypaert [23] through empirically investigate found that horizontal mergers and acquisitions to increase industry concentration can help companies achieve market power.

But if Internet companies cannot monopolize the market and control customers, they are very likely to be quickly eliminated by the market [24]. But Faulhaber [25] analysis the AOL-Time Warner merger and result show that due to the special nature of the network, the network effect may cause anti-trust concerns, which is not conducive to the development of the industry in the long term and may lead to inefficiency.

The power of monopoly will limit the function of a more efficient market competition mechanism. In the long run, it will result in a lack of efficiency of the monopoly itself.

\section{3) Valuation theory}

Bradley, Desai and Kim [26] analysis CAR of 472 companies and found that whether acquisitions will eventually achieve good results, the valuation of the target company will often be improved. But if the price of the acquisition is higher than the value of the target company, the financial performance of the bidding company will be damaged for a long time and no synergies can be produced [27].

The value and market potential of Internet companies are often overestimated [28]. Wang and Zhang [29] analysed the merger and acquisition projects of Baidu, Alibaba and Tencent, the result pointed out, in the Internet corporation's M\&As, the degree of relatedness between the businesses of the buyer and seller is positively associated with the corporate value. Yang and $\mathrm{Li}$ [30] used the economic value added (EVA) calculation method to evaluate the value of mergers and acquisitions by Internet companies, it pointed out that mergers and acquisitions of listed companies on the Internet will have a positive impact on corporate stock prices For Internet companies, a significant feature of the high-tech industry is the inherent uncertainty associated with companies whose value depends on the development of unknown areas in the future [31].

Corporate mergers and acquisitions can increase Internet corporate value, but mergers and acquisitions processes, strategies, and subsequent integration can have a greater impact on corporate value.

\section{4) Agency theory}

The agency motives show that acquisitions take place because they increase the welfare of the acquirer's management at the expense of the acquirer's shareholders. This may not be in the overall interest of the company.

Jensen [32] believes that managers may have the incentive to expand the company to the best scale. The reason is that growth usually increases management power and compensation. Berkovitch and Narayanan [33] through a hypothesis experiment with bid prices as a sample from 1963 to 1988 found that agency hypotheses imply a negative correlation and inconsistency of goals and objectives of managers and shareholders. One of the most common reasons for merger failure is that managers are overconfident because they tend to think that their actions will maximize their value [34]. Malmendier and Tate [35] through CEO sample measurement and point out that agency problems and overconfidence may lead to excessive mergers and acquisitions.

Liu and $\mathrm{Li}$ [36] based on the theory of synergy, concluded that the merger and acquisition of the Internet industry is the choice of the strategic layout of the company, but it may also be due to the emergence of mergers and acquisitions caused by the arrogance of managers.

\section{RESEARCH METHOD}

\section{A. Event Analysis}

Event research method is a commonly used short-term performance research method. The basic method is to find 
out the abnormal returns attributed to event research by adjusting the returns due to the overall market price fluctuations [37].

\section{1) Capital asset pricing model}

MacKinlay [38] believes that the most common model of normal returns is the market model. The model means that the estimation window (usually 120 days) is used before the event and the relationship between the company's stock and the reference index is obtained through regression analysis. Based on the regression coefficients, normal earnings are then calculated and used to calculate abnormal returns. This study will use the Capital Asset Pricing Model (CAPM) model to analyze events.

The precondition for the use of this method is that the securities market must be fully effective [39]. Youku and Tudou listed in the United States, and the US stock market is Semi-strong-form efficiency. Therefore, this study uses event research to perform the short-term performance analysis of Youku merge with Tudou.

\section{2) Capital asset pricing model process}

The first step is to select the event day and event window period. The day of the event was the first public announcement date. On the timeline, define it as 0 . Then, using zero points as a centre point, extend $\mathrm{N}$ days forward and backwards on the time axis, that is, define $[-\mathrm{N}, \mathrm{N}]$ as a complete event period. In the study, the $\mathrm{N}$ selected by this study is 5 , which is defined as $[-5,5]$.

The second step is to determine the clean-up period of the event. In general, the clean-up period is set in front of the window period. Therefore, this study is set to clean-up period $(-116,-6)$.

The third step is to calculate the daily rate of return of the company's stock and the daily return of the market index in the case of the collection of relevant data. In December 2010 and August of the following year, Youku and Tudou were listed on the New York Stock Exchange and Nasdaq. Therefore, this study selects the S\&P 500 Index to calculate market data for the expected rate of return.

The fourth step is the calculation of the normal rate of return. The method used for this calculation is the market adjustment model method. First, determine a cleanup period; then, substitute the data into the regression equation; finally, calculate the normal rate of return. Among them, the sample, explanatory variables and explained variables are estimated period data, market index return rate and stocks return rate. This method considers two important factors: risk factors, average returns.

The calculation of the normal rate of return is based on the CAPM calculation. In the linear regression analysis, the clean-up period data, the explanatory variable, and the explanatory variable are the data of the period $[-116,-6]$, the actual return rate of the company's stock, and the market index.

\section{B. Regression equation:}

$$
R_{i t}=\alpha_{i}+\beta_{i} R_{m t}+\varepsilon_{i t}
$$

$R_{i t} \quad$ The actual daily yield of the $\mathrm{i}$-th stock on the $\mathrm{t}$-day

$R_{m t}$ Market Index Daily Yield on Day $\mathrm{t}$

$\alpha_{i} \quad$ The intercept of the regression equation

$\beta_{i} \quad$ The slope of the regression equation $\varepsilon_{i t} \quad$ Residual value

With the closing prices of day $\mathrm{t}$ and day $\mathrm{t}-1$, the value of $\mathrm{R}_{\text {it }}$ it can be obtained:

$$
R_{i t}=\frac{P_{i t}}{P_{i(t-1)}}-1(t \sim(-116,-6])
$$

So

$$
R_{m t}=\frac{P_{m t}}{P_{m(t-1)}}-1(t \sim(-116,-6])
$$

$P_{i t} \quad$ T-day closing price of individual stocks

$P_{i(t-1)}$ Stocks t-1 day closing price

$P_{m t} \quad$ Market index t day closing price

$P_{m(t-1)}$ The market index t-1 day's closing price.

After the regression, $\mathrm{A}$ and $\mathrm{N}$ are obtained, and the normal yield is brought into Equation 3-1:

$$
\widehat{R_{l t}}=\alpha_{i}+\beta_{i} R_{m t} t
$$

The fifth step is to calculate the daily abnormal return (AR). Get the stock's normal yield $\widehat{\mathrm{R}_{\mathrm{lt}}}$ and calculate each stock's daily AR in the event period $[-5,5]$, that is

$$
\mathrm{A} R_{i t}=R_{i t}-\widehat{R_{l t}}(t \sim[-5,5])
$$

The sixth step calculates the CAR. Calculate the cumulative excess $\mathrm{CAR}_{\mathrm{t}}$ of all stocks during the event period $[-5,5]$.

$$
C A R_{t}=\sum_{t=5}^{t} A \operatorname{Rit}(t \sim[-5,5])
$$

\section{Financial Indicators Analysis}

The analysis method of financial indicators is to analyze the financial data of the company before and after the merger and acquisition and use the relevant financial indicators of the company performance evaluation as the standard [40]. Therefore, the financial indicator analysis method has strong availability. The main financial indicators are as follows.

\section{1) Profitability analysis}

The ultimate profit is one of the most important reasons for the M\&A activity of the company. The ability to gain profits can be illustrated by measuring profitability indicators [41].

This study will use the following related formulas: Sales

Gross Profit Margin $=($ Net Sales - Product Cost $) / \mathrm{Net}$

Net Profit Margin = Net Profit/Sales Revenue

Return on Equity = Net Income/Book Value of Equity

Return on Assets = Net Income/Average Total Assets

\section{2) Operating capacity analysis}

The operating capacity analysis reflects the efficiency of the company's use of assets. if the occurrence of mergers and acquisitions will significantly improve corporate asset management capabilities, then it can also achieve its goal of profit [42].

This study will use the following related formulas:

Account Receivable Turnover Ratio $=$ Net Credit Sales/Average Accounts Receivable 
Current Assets Turnover Ratio $=$ Sales revenue/Average current assets.

Total Assets Turnover Ratio $=$ Net Sales/Average Total Assets

\section{3) Growth capability analysis}

The growth capability represents the company's future development trend, which is mainly reflected in the expansion of business scale, operating income, and operating profit growth [43]. M\&A is an effective way to expand the scale of enterprises to achieve economies of scale.

This study will use the following related formulas:

Increase Rate of Main Business Revenue $=($ Total Revenue of This Year- total revenue of Last Year) / Total Operating Income of Last Year

Increase Rate of Net loss $=($ Net profit of This Year- Net profit of Last Year)/ Net profit of Last Year

Total Assets Growth Rate $=($ Total assets at the end of the year - Total assets at the beginning of the year) / Total assets at the beginning of the year

\section{DATA DESCRIPTION AND DATA ANALYSIS}

\section{A. CAPM}

Youku and Tudou signed a merge agreement on March 11th, according to the theory of effective market hypothesis, the disclosure date of March 12 should be set as the event day. In this case, five trading days before and after the event: the data from March 5, 2012 to March 19, 2012 is the event window, and the estimation window is from September 23, 2011 to March 2, 2012.

According to the setting of Chapter 2, this section analyses the impact of M\&A events on the short-term performance of Youku. The results are reported in Fig 3.1 and Fig 3.2. On the day of the M\&A announcement (March 12 , 2012), Youku's abnormal return rate was $26.95 \%$. However, after the M\&A announcement date, the stock price continued to decline until the fourth day after the M\&A announcement date. From the point of cumulative abnormal return, Youku has received a positive cumulative abnormal return of $21.30 \%$ as of the date of the merger announcement, which is significant at the $1 \%$ level. But as of March 19, 2012, the cumulative abnormal return was negative, but not significant. Overall, on the day of the M\&A announcement, the market responded positively to Youku merge with Tudou, it shows a positive short-term effect.

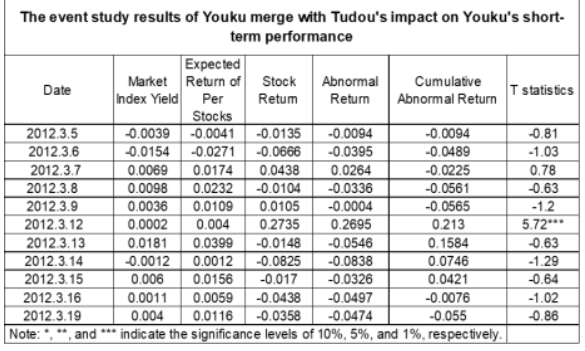

Fig. 1. The Event Study Results of Youku Merge with Tudou's Impact on Youku's Short-Term Performance Table

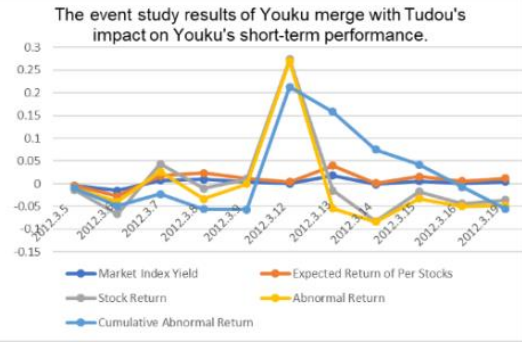

Fig. 2. The Event Study Results of Youku Merge with Tudou's Impact on Youku's Short-Term Performance

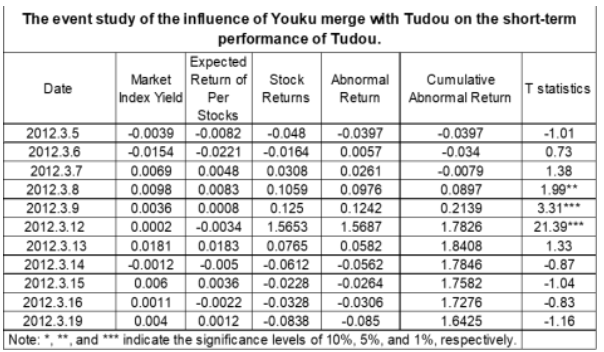

Fig. 3. The Event Study of The Influence of Youku Merge with Tudou On the Short-Term Performance of Tudou Table

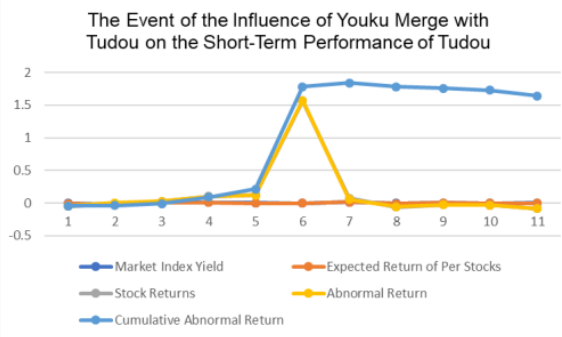

Fig. 4. The Event Study of The Influence of Youku Merge with Tudou On the Short-Term Performance of Tudou

Further, this section examines the impact of this acquisition on Tudou's short-term return. The results are shown in Fig 3.3 and Fig 3.4. Observe that this acquisition event has a positive impact on Tudou in the short term. On the day of M\&A announcement, Tudou obtained the abnormal return of $156.87 \%$, which was significantly higher than $26.95 \%$ of Youku. As of the announcement date, Tudou's cumulative abnormal return was $178.36 \%$, and it was significant at the $1.0 \%$ level. This shows that for Tudou, the investors made a more positive response.

\begin{tabular}{|c|c|c|c|c|c|c|}
\hline \multicolumn{4}{|c|}{ Youku merge with Tudou synergies with the two companies } \\
\hline & \multicolumn{3}{|c|}{ Abnomal Return } & \multicolumn{3}{c|}{$\begin{array}{c}\text { Abnomal Return Valuation } \\
\text { (billions of dollars) }\end{array}$} \\
\hline Date & Youku & Tudou & Total & Youku & Tudou & Total \\
\hline 2012.3 .5 & -0.0094 & -0.0397 & -0.0491 & 0.2778 & 0.1808 & 0.4586 \\
\hline 2012.3 .6 & -0.0395 & 0.0057 & -0.0338 & 1.4326 & 0.9972 & 2.4298 \\
\hline 2012.3 .7 & 0.0264 & 0.0261 & 0.0525 & 0.6150 & 0.2173 & 0.8323 \\
\hline 2012.3 .8 & -0.0336 & 0.0976 & 0.064 & 1.6026 & 2.5608 & 4.1634 \\
\hline 2012.3 .9 & -0.0004 & 0.1242 & 0.1238 & 1.5967 & 6.0435 & 7.6402 \\
\hline 2012.3 .12 & 0.2695 & 1.5687 & 1.8382 & 6.0827 & 16.9659 & 23.0486 \\
\hline 2012.3 .13 & -0.0546 & 0.0582 & 0.0036 & 5.7602 & 22.3112 & 28.0714 \\
\hline 2012.3 .14 & -0.0838 & -0.0562 & -0.14 & 2.6738 & 21.3114 & 23.9852 \\
\hline 2012.3 .15 & -0.0326 & -0.0264 & -0.059 & 1.3824 & 19.2628 & 20.6452 \\
\hline 2012.3 .16 & -0.0497 & -0.0306 & -0.0803 & 0.2464 & 18.6053 & 18.8517 \\
\hline 2012.3 .19 & -0.0474 & -0.085 & -0.1324 & 1.7005 & 16.9146 & 18.6151 \\
\hline
\end{tabular}

Fig. 5. Youku Merge with Tudou Synergies with The Two Companies

Finally, the short-term synergy estimate is equal to the total value of Youku and Tudou's CAR multiplied by their respective day before the event window. The synergy analysis results produced by Youku merge with Tudou are shown in Fig 3.5. It can be found that on the day of M\&A announcement, the two companies received a total of $183.82 \%$ of the abnormal return. On the news disclosure day, the total CAR of Youku and Tudou was US\$ 2.807 billion, which was significantly higher than the US\$ 774 million in the previous trading day. As of the last day of the study's event window, 
on March 19, 2012, the total market value of the merger for the two companies brought in approximately US\$1.862 billion in cumulative abnormal return, of which Youku and Tudou were US\$170 million and US\$1.692 billion, respectively. This shows again that this merger and acquisition incident has brought positive returns to both companies, but the positive impact on Tudou is significantly greater than that of Youku.

\section{B. Financial Indicators Analysis}

\section{1) Profitability Analysis}

Fig 3.6 reflects the changes in the profitability of Youku and Tudou. As can be seen from the related indicators in Fig 3.6, Youku's profitability before the merger is stronger than Tudou. After the merger, the gross profit margin is higher than the gross profit margin before the merger, which indicates that the merger and acquisition activity still gives Youku strong profitability. The net profit margin indicator changes show that both Youku and Tudou's net profit margin after the merger was stronger than before the merger, but it declined in 2014, indicating that the loss still exists. Return on equity and return on total assets have a similar situation. However, after the merger and acquisition of the two indicators have appeared in the first increase and then drop the process, indicating that the ability to use assets to obtain profit changes is not great.

So, after the merger, Youku Tudou Inc.'s operating income has been greatly improved, gross profit margin has risen steadily, losses have gradually narrowed, and initial success has been achieved.

\begin{tabular}{|c|r|r|r|r|r|c|c|}
\hline & $\begin{array}{c}\text { Youku } \\
(2010)\end{array}$ & $\begin{array}{c}\text { Tudou } \\
(2010)\end{array}$ & $\begin{array}{c}\text { Youku } \\
(2011)\end{array}$ & $\begin{array}{c}\text { Tudou } \\
(2011)\end{array}$ & $\begin{array}{c}\text { Youku Tudou } \\
\text { Inc. (2012) }\end{array}$ & $\begin{array}{c}\text { Youku Tudou } \\
\text { Inc. (2013) }\end{array}$ & $\begin{array}{r}\text { Youku Tudou } \\
\text { Inc. (2014) }\end{array}$ \\
\hline $\begin{array}{c}\text { Gross Profit } \\
\text { Margin }\end{array}$ & $9.37 \%$ & $20.89 \%$ & $22.31 \%$ & $16.46 \%$ & $16.63 \%$ & $17.73 \%$ & $19.16 \%$ \\
\hline $\begin{array}{c}\text { Net Profit } \\
\text { Margin }\end{array}$ & $-52.95 \%$ & $-121.35 \%$ & $-19.17 \%$ & $-99.79 \%$ & $-21.09 \%$ & $-19.55 \%$ & $-22.03 \%$ \\
\hline $\begin{array}{c}\text { Return on } \\
\text { Equity }\end{array}$ & $-18.58 \%$ & $-257.90 \%$ & $-4.09 \%$ & $-76.26 \%$ & $-5.95 \%$ & $-6.54 \%$ & $-7.73 \%$ \\
\hline $\begin{array}{c}\text { Return on } \\
\text { Assets }\end{array}$ & $-15.57 \%$ & $-72.24 \%$ & $-3.68 \%$ & $-42.75 \%$ & $-5.21 \%$ & $-5.62 \%$ & $-6.45 \%$ \\
\hline
\end{tabular}

Fig. 6. Youku Tudou Inc. Profitability Analysis

\section{2) Operating capacity analysis}

This section mainly uses the three key financial indicators in Fig 3.7 to measure the change in the operating capacity before and after the merger of two companies.

\begin{tabular}{|c|c|c|c|c|c|c|c|}
\hline \multicolumn{7}{|c|}{ Youku Tudou Inc. Operating Capacity Analysis } \\
\hline & $\begin{array}{c}\text { Youku } \\
(2010)\end{array}$ & $\begin{array}{c}\text { Tudou } \\
(2010)\end{array}$ & $\begin{array}{c}\text { Youku } \\
(2011)\end{array}$ & $\begin{array}{c}\text { Tudou } \\
(2011)\end{array}$ & $\begin{array}{c}\text { Youku Tulou } \\
\text { Inc. (2012) }\end{array}$ & $\begin{array}{c}\text { Youku Tudou } \\
\text { Inc. (2013) }\end{array}$ & $\begin{array}{c}\text { Youku Tudou } \\
\text { Inc. (2014) }\end{array}$ \\
\hline $\begin{array}{c}\text { Account Receivable } \\
\text { Turnover }\end{array}$ & 2.83 & 1.78 & 2.91 & 2.09 & 2.82 & 2.67 & 2.52 \\
\hline $\begin{array}{c}\text { Current Assets } \\
\text { Turnover }\end{array}$ & 0.32 & 0.68 & 0.21 & 0.53 & 0.42 & 0.64 & 0.52 \\
\hline $\begin{array}{c}\text { Total Assets } \\
\text { Turnover }\end{array}$ & 0.29 & 0.59 & 0.26 & 0.42 & 0.24 & 0.28 & 0.29 \\
\hline
\end{tabular}

Fig. 7. Youku Tudou Inc. Operating Capacity Analysis

Account receivable turnover data changes show that the performance of Youku before the merger was significantly better than Tudou. However, it is weaker than Tudou in current assets turnover and total assets turnover. This is because the difference between Youku and Tudou's operating income is not very big, but Youku's assets are larger. Youku's account receivable turnover showed a steady decline. However, through the merger and acquisition activity, Tudou's account receivable turnover has been improved. About current assets turnover and total assets turnover, Youku's current assets turnover has improved significantly. The two indicators of Tudou's change are not very obvious, which is due to the small scale of the current assets and total assets of Tudou before the acquisition.
After Youku merge with Tudou, M\&A activity has only played a limited positive role in the improvement of operational efficiency.

\section{3) Growth capability analysis}

This section measures changes in the growth ability of Youku and Tudou before and after M\&A from three indicators in Fig 3.8. The growth rate in 2012 is relative to the sum of the two companies in 2011, because M\&A activity was completed in 2012.

\begin{tabular}{|c|c|c|c|c|c|c|c|}
\hline \multicolumn{8}{|c|}{ Youku Tudou Inc. Growth Capability Analysis } \\
\hline & $\begin{array}{l}\text { Youku } \\
(2010)\end{array}$ & $\begin{array}{l}\text { Tudou } \\
\text { (2010) }\end{array}$ & $\begin{array}{l}\text { Youku } \\
\text { (2011) }\end{array}$ & \begin{tabular}{|l} 
Tudou \\
(2011)
\end{tabular} & $\begin{array}{l}\text { Youku Tudou } \\
\text { he. }(2012)\end{array}$ & $\begin{array}{l}\text { Youk Tudou } \\
\text { he }(2013)\end{array}$ & $\begin{array}{l}\text { Youku Tubou } \\
\text { is (2014) }\end{array}$ \\
\hline $\begin{array}{l}\text { nerease Rate of } \\
\text { Main Business } \\
\text { Revenent }\end{array}$ & $151.90 \%$ & $152.84 \%$ & 131. $85 \% \mathrm{~F}$ & $78.62 \%$ & $35.46 \%$ & $60.69 \%$ & $31.90 \%$ \\
\hline $\begin{array}{c}\text { Merease Rate of } \\
\text { Net loss }\end{array}$ & $12.45 \%$ & $133.46 \%$ & $-16.04 \%$ & $47,13 \%$ & $-41.04 \%$ & $48.98 \%$ & $4865 \%$ \\
\hline $\begin{array}{l}\text { Total Assests } \\
\text { Grown Rate }\end{array}$ & $395.80 \%$ & $16568 \%$ & $113.47 \%$ & $142.22 \mathrm{~m}$ & $60.48 \%$ & $-2.16 \%$ & $61.80 \%$ \\
\hline
\end{tabular}

Fig. 8. Youku Tudou Inc. Growth Capability Analysis

The total assets growth rate reflects the extent of business expansion. Prior to the merger, the two companies' assets expanded rapidly. After the merger, the total asset growth rate first showed a downward trend and then rebounded. It indicated that there is no rapid expansion of demand.

The data on the increase rate of main business revenue shows that the growth rate after mergers and acquisitions is weaker than that before mergers and acquisitions, but it tends to be flat after the merger and acquisition. The net loss indicator shows that the net loss before merger and acquisition is gradually decreasing, indicating that the degree of loss is decreasing. After the merger and acquisition, the net loss growth rate has stabilized, but the net loss is still slowly expanding.

In a comprehensive view, M\&A performance begins to show positive. However, the change is not very obvious and needs further analysis from a long-term perspective.

\section{CONCLUSION}

The study used Youku merge with Tudou as a case and used many valuable data to discover the motivation and performance of Internet companies' M\&A in the new era. And this study found that the traditional theory of mergers and acquisitions can still continue to explain some of the problems of modern Internet companies' mergers and acquisitions.

The results of the study show that the motives for mergers and acquisitions of Internet companies in China still include synergies, strengthening market competitiveness, increasing corporate value, and agency issues. M\&A behavior can bring about a short-term positive impact on corporate performance. The results of the study partially comply with the results of the discussion in the literature review.

\section{REFERENCE}

[1] Research.pedaily.cn. Annual Research Report on China's M\&A Market in 2012_Zero2ipo Report_Investment Sector: The Most Authoritative Investment Industry Report. [online] Available at: http://research.pedaily.cn/report/free/792.shtml, 2013

[2] Cnnic.cn. China Internet Network Information Center. [online] Available at: http://www.cnnic.cn/gywm/Xwzx/rdxw/201801/t20180131_70188.ht $\underline{\mathrm{m}}, 2018$

[3] iResearch.pedaily.cn. Annual Research Report on China's M\&A Market in 2012_Zero2ipo Report_Investment Sector: The Most 
Authoritative Investment Industry Report. [online] Available at: http://research.pedaily.cn/report/free/792.shtml, 2013

[4] Y. Li, and X. Guo, Research and Enlightenment of M\&A Literature of Internet Enterprises in the New Era. Foreign Economic Relations \& Trade, 2016, (11):75-76

[5] S. Lebedev, M. Peng, E. Xie, and C. Stevens, Mergers and acquisitions in and out of emerging economies. Journal of World Business, 2015, 50(4):651-662.

[6] K. Uhlenbruck, M. Hitt, and M. Semadeni, Market value effects of acquisitions involving internet firms: a resource-based analysis. Strategic Management Journal, 2006, 27(10):899-913.

[7] S. Myers, and N. Majluf, Corporate financing and investment decisions when firms have information that investors do not have. Journal of Financial Economics, 1984, 13(2):187-221.

[8] E. Lehto, and M. Lehtoranta, Becoming an acquirer and becoming acquired. Technological Forecasting and Social Change, 2004, 71(6):635-650.

[9] Wang, X. Research on M\&A Performance of InternetEnterprises. Capital University of Economics and Business, 2013

[10] Salinger, M.. Vertical Mergers in Multi-Product Industries and Edgeworth's Paradox of Taxation. The Journal of Industrial Economics, 1991, 39(5):545.

[11] A. Agrawal, J. Jaffe, and G. Mandelker, The Post-Merger Performance of Acquiring Firms: A Re-Examination of an Anomaly. The Journal of Finance, 1992, 47(4):1605.

[12] A. Seth, K. Song, and R. Pettit. Value creation and destruction in cross-border acquisitions: an empirical analysis of foreign acquisitions of U.S. firms. Strategic Management Journal, 2002, 23(10): 921-940.

[13] Fulghieri, P. and Sevilir, M. Mergers and Incentives to Create Synergies. SSRN Electronic Journal, 2012

[14] Wang, L. and Liu, Z. Research on Strategic Mergers and Acquisitions in Internet Industry and Financial Synergy--A Case Study on Baidu's M\&A of Qunar. Journal of Beijing Technology And Business University (Social Sciences), 2014, (6):47-54

[15] M. Hitt, R. Freeman, and J. Harrison, The Blackwell handbook of strategic management. Blackwell, 2001

[16] A. Slusky, and R. Caves. Synergy, Agency, and the Determinants of Premia Paid in Mergers. The Journal of Industrial Economics, 1991, 39(3):277.

[17] E. Zajac, and J. Westphal, Accounting for the Explanations of CEO Compensation: Substance and Symbolism. Administrative Science Quarterly, 1995, 40(2):283.

[18] H. Yang, Research on the Risk and Precaution of China's Internet Enterprises after Mergers and Acquisitions. Shandong University, 2010

[19] X. Ma, Internet Enterprise Mergers and Acquisitions Risk Control Research. Inner Mongolia University, 2014.

[20] D. Zhao, and S. Wang, The Relationship between M \& A Behavior and Innovation Performance of Internet Corporations. Shanghai Management Science, 2015, (3):7-12.

[21] C. Fee, and S. Thomas, Sources of gains in horizontal mergers: evidence from customer, supplier, and rival firms. Journal of Financial Economics, 2004, 74(3):423-460.

[22] H. Shahrur, Industry structure and horizontal takeovers: Analysis of wealth effects on rivals, suppliers, and corporate customers. Journal of Financial Economics, 2005, 76(1):61-98

[23] N. Huyghebaert, and M. Luypaert, Antecedents of growth through mergers and acquisitions: Empirical results from Belgium. Journal of Business Research, 2010, 63(4):392-403.

[24] T. Lan, Analysis of Financial Synergy of Mergers and Acquisitions in Internet Enterprises. Market Modernization, 2015, (4):206-207.

[25] G. Faulhaber, Network Effects and Merger Analysis: Instant Messaging and The Aol - Time Warner Case $i s$. Telecommunications Policy, 2002, 26(5):311-333.

[26] M. Bradley, A. Desai, and E. Kim, Synergistic gains from corporate acquisitions and their division between the stockholders of target and acquiring firms. Journal of Financial Economics, 1998, 21(1):3-40

[27] C. Widensky, The top 10 tips to successful practice acquisitions. Journal of the New Jersey Dental Association, 2014, 85(1):26.

[28] Z. Wang, and D. Zhang, Research on the Impact of Internet M\&A on the Value of the Firm: The Case Study on BAT. Accountant, 2016, (19):78-79.
[29] Y. Wang. Research on the Value Creation of M\&A in Internet Enterprises. Modern Business Trade Industry, 2015, 36(4):9-10.

[30] L. Yang. and L. Li. Using Eva Calculation Method to Evaluate the Synergy Effect of Internet Company's Merger Value. Appraisal Journal of China, 2016, (5):37-39.

[31] D. Lusyana. and Sherif, M. Do mergers create value for high-tech firms? The hounds of dotcom bubble. The Journal of High Technology Management Research, 2016, 27(2):196-213.

[32] M. Jensen. Agency cost of free cash flow, corporate finance, and takeovers. American Economic Review, 1986, 76(2):323-329.

[33] E. Berkovitch, and M.P. Narayanan, Motives for takeovers: an empirical investigation. Journal of Financial \& Quantitative Analysis, 1993, 28(3):347-362.

[34] H. Shefrin, Behavioral Finance: Biases, Mean-Variance Returns, and Risk Premiums. CFA Institute Conference Proceedings Quarterly, 2007, 24(2):4-12

[35] U. Malmendier, and G. Tate, Behavioral CEOs: the role of managerial overconfidence. Journal of Economic Perspectives, 2015 29(4):37-60.

[36] X. Liu, and C. Li, Mobile Internet Industry and Merger and Acquisition Analysis. Modern Business, 2012, (35):123-124.

[37] R. Gilson, The law and finance of corporate acquisitions. Westbury, N.Y.: Foundation Press, 1999.

[38] A.C. Mackinlay, Event studies in economics and finance. Journal of Economic Literature, 1997, 35(1):13-39.

[39] H.M. Markowitz, Portfolio selection: efficient diversification of investment. Journal of the Institute of Actuaries, 1959, 119(1):243-265.

[40] P. Asquith,. Lessons in Corporate Finance. Wiley, 2016

[41] D. Hillier, S. Ross, R. Westerfield, J. Jaffe, and Jordan, B. Corporate finance. New York, N.Y.: McGraw-Hill Education, 2016

[42] J. Berk, and P. DeMarzo, Corporate finance. Harlow: Pearson Education Limited, 2017

[43] R. Brealey, S. Myers, and F. Allen, Principles of corporate finance. New York, NY: McGraw-Hill Education, 2017. 